\title{
Vacuum Steam Treatment Eradicates Viable Bretziella fagacearum from Logs Cut from Wilted Quercus rubra
}

Jennifer Juzwik, Northern Research Station, USDA Forest Service, St. Paul, MN; Anna Yang, Department of Forest Resources, University of Minnesota, St. Paul; Zhangjing Chen ${ }^{\dagger}$ and Marshall S. White, Department of Sustainable Biomaterials, Virginia Polytechnic Institute and State University, Blacksburg; and Sarah Shugrue and Ronald Mack, Otis Laboratory, USDA Animal and Plant Health Inspection Service, Plant Protection and Quarantine, Buzzards Bay, MA

\begin{abstract}
Methyl bromide (MB) fumigation is required for U.S. Quercus log exports due to concern over unintentional spread of Bretziella fagacearum. MB alternatives are needed due to the chemical's ability to damage the earth's ozone layer. Vacuum steam (VS) is an environmentally friendly method that was evaluated for its ability to eradicate $B$. fagacearum in logs $(24$ to $61 \mathrm{~cm}$ diameter; 1.7 to $1.9 \mathrm{~m}$ long) obtained from $Q$. rubra that had wilted following natural infection (NI) or artificial inoculation (AI). Five replicate loads of two NI and one AI logs were VS-treated at $56^{\circ} \mathrm{C}$ for $30 \mathrm{~min}$ and $60^{\circ} \mathrm{C}$ for

$60 \mathrm{~min}$ (at $5.0 \mathrm{~cm}$ sapwood depth). Mean frequencies of pretreatment fungus colonization ranged from 12.5 to $24.4 \%$ in $\mathrm{NI}$ and 29.4 to $45.6 \%$ in $\mathrm{AI} \operatorname{logs}$ based on isolation from wood chips of inner and outer sapwood, respectively, of two disks per log. Frequencies of pathogen DNA detection were similar to those for isolation. No viable pathogen or its DNA were detected in posttreatment logs. Treatment times ranged from 5 to $9 \mathrm{~h}$ for the $56^{\circ} \mathrm{C} /$ $30 \mathrm{~min}$ schedule and from 8 to $10 \mathrm{~h}$ for the $60^{\circ} \mathrm{C} / 60 \mathrm{~min}$ schedule. Based on these results, VS is worthy of further development as a MB alternative.
\end{abstract}

Oak wilt, caused by Bretziella fagacearum (Bretz) Z.W. deBeer, Marinc., T.A. Duong, \& M.J. Wingf. (syn. Ceratocystis fagacearum (Bretz) Hunt), is an important disease of Quercus species known to occur only in the eastern United States and of regulatory concern within and outside the country. It is not known to occur in any other countries. Fumigation with methyl bromide (MB) is required for oak logs destined for export from the United States due to the concern over potential, unintentional spread of the pathogen. The current fumigation schedule $\left(240 \mathrm{~g} / \mathrm{m}^{3}\right.$ for $\left.72 \mathrm{~h}\right)$ for oak logs is one of the highest recommended schedules for quarantine and preshipment (QPS) commodity use (USDA APHIS 2016). MB was officially recognized as a controlled ozone-depleting substance in a 1992 amendment to the Montreal Protocol, an international treaty under the United Nations Environmental Program (UNEP 2002). Signatories of the agreement recognized two phase-out dates, 2005 for industrialized countries and 2015 for developing countries, for most uses of the chemical. However, an exemption was made for the use of MB for QPS purposes. In 2009, the use of MB for QPS was recognized as the largest use category of any halogenated gas known to cause severe damage to the earth's ozone layer (Pizano and Banks 2009). This same review also estimated that $21 \%$ of all MB applied for QPS purposes was used for controlling quarantine pests in whole logs. Thus, alternatives to MB for oak log treatment are urgently needed.

Alternative fumigants and heat treatments have been evaluated for toxicity to the fungus or for their ability to eradicate viable $B$. fagacearum in oak logs for over five decades (Jones 1973; MacDonald et al. 1985; Partridge 1961; Schmidt et al. 1997; Tubajika and Barak 2011; Uzunovic et al. 2017). After oak wilt was first discovered (1942), several countries would not import oak logs from the United States unless they were USDA-certified to be from outside the known disease range or had been kiln-dried so wood moisture was $\leq 20 \%$.

${ }^{\dagger}$ Corresponding author: Z. Chen; E-mail: chengo@vt.edu

Funding: This research was partially funded by the USFS FHP Washington Office.

*The $\boldsymbol{e}$-Xtra logo stands for "electronic extra" and indicates that one supplementary figure and one supplementary table is published online.

Accepted for publication 2 August 2018.

This article is in the public domain and not copyrightable. It may be freely reprinted with customary crediting of the source. The American Phytopathological Society, 2019.
Although conventional hot air is useful for phytosanitary treatment of some wood products (e.g., firewood), it is not acceptable for logs due to deleterious degrade issues, e.g., checking and discoloration in veneer $\operatorname{logs}$ (Chen et al. 2017a). Hot air and hot water immersion treatments were reported to eradicate B. fagacearum from 0.9m-long main stem sections cut from trees ranging from 28 to $42 \mathrm{~cm}$ diameter at $1.4 \mathrm{~m}$ height (dbh) (Jones 1973). Sections were from three different red oak species that had wilted following artificial inoculation with the pathogen. To our knowledge, no further testing with commercial size logs or operational-scale testing using the proposed schedules has been reported. The current MB schedule used for treatment of oak logs for export from the United States is based on a series of trials conducted in the late 1970s and early 1980s (MacDonald et al. 1985; Schmidt 1983), and was specifically designed to target the sapwood zone where B. fagacearum is found.

Alternative fumigants have been investigated for their ability to eradicate viable $B$. fagacearum from oak logs. However, analysis of fungitoxicity as a function of concentration $\times$ time $(\mathrm{CT})$ has often been complicated by issues surrounding penetration (e.g., high wood moisture, bark adsorption) (UNEP 2002; Woodward and Schmidt 1995). Sulfuryl fluoride (SF) has been evaluated in both laboratory and larger log studies as an alternative to MB since the early $1990 \mathrm{~s}$ for the fumigant's ability to kill B. fagacearum in colonized oak sapwood (Schmidt et al. 1997; Tubajika and Barak 2011; Uzunovic et al. 2017; Woodward and Schmidt 1995). Although SF penetration of wood is superior to $\mathrm{MB}$, higher treatment rates and application at higher temperatures than normally used for $\mathrm{MB}$ are required (Scheffrahn et al. 1992). In a recent trial, B. fagacearum in logs $(1.2 \mathrm{~m}$ long) from naturally infected and from artificially inoculated Q. ellipsoidalis E.J. Hill was not completely eradicated by SF treatments $\left(280 \mathrm{~g} / \mathrm{m}^{3}\right.$ and $320 \mathrm{~g} / \mathrm{m}^{3}$ for $72 \mathrm{~h}$ ) (Juzwik et al. 2017). Based on trials with $B$. fagacearum-colonized wood blocks of red oak, maple, poplar, birch, and pine, methyl iodide was found to be more effective than SF in killing the pathogen (Tubajika and Barak 2011). Methyl iodide has been shown to kill B. fagacearum at rates similar to MB (Tubajika and Barak 2006).

Nonchemical alternatives for commercial oak log treatment are also of current interest. Pest and pathogen risks associated with imported hardwood veneer logs have been mitigated in New Zealand using hot water and steam treatment (Pizano and Banks 2009). In a recent study, vacuum and steam (VS) processing was used to sanitize low quality ash logs and ash firewood (Chen et al. 2017b). Research has also been conducted on vacuum and steam processing (200 $\mathrm{mmHg}$ vacuum and steam heat of $56^{\circ} \mathrm{C}$ to the $\log$ core for $30 \mathrm{~min}$ ) of three veneer-grade red oak logs (mean diameter 
$50 \mathrm{~cm}$; mean length $2.5 \mathrm{~m}$ long), which exhibited some end-checking to a depth of $2.5 \mathrm{~cm}$ following treatment, but no color change was detected in veneer samples following log slicing (Chen et al. 2017a). The time required for treatment ranged from 15.5 to $26 \mathrm{~h}$, which is substantially less than the $72 \mathrm{~h}$ required for current commercial treatment with MB (USDA APHIS 2016). Based on results of previously cited studies, outdoor experiments were undertaken to evaluate the ability of the VS process to kill B. fagacearum in logs from larger diameter Quercus rubra L. trees using a portable treatment chamber. The specific objectives were to: 1 ) determine the rate of $B$. fagacearum isolation from two sapwood depths prior to VS treatment for logs from naturally infected (NI) and artificially inoculated (AI) $Q$. rubra that had completely wilted by time of tree felling, 2) determine the pathogen isolation rates following treatment at either $56^{\circ} \mathrm{C}$ for $30 \mathrm{~min}$ or $60^{\circ} \mathrm{C}$ for $60 \mathrm{~min}$ to $5.0 \mathrm{~cm}$ depth into the wood, and 3) document temperatures achieved at

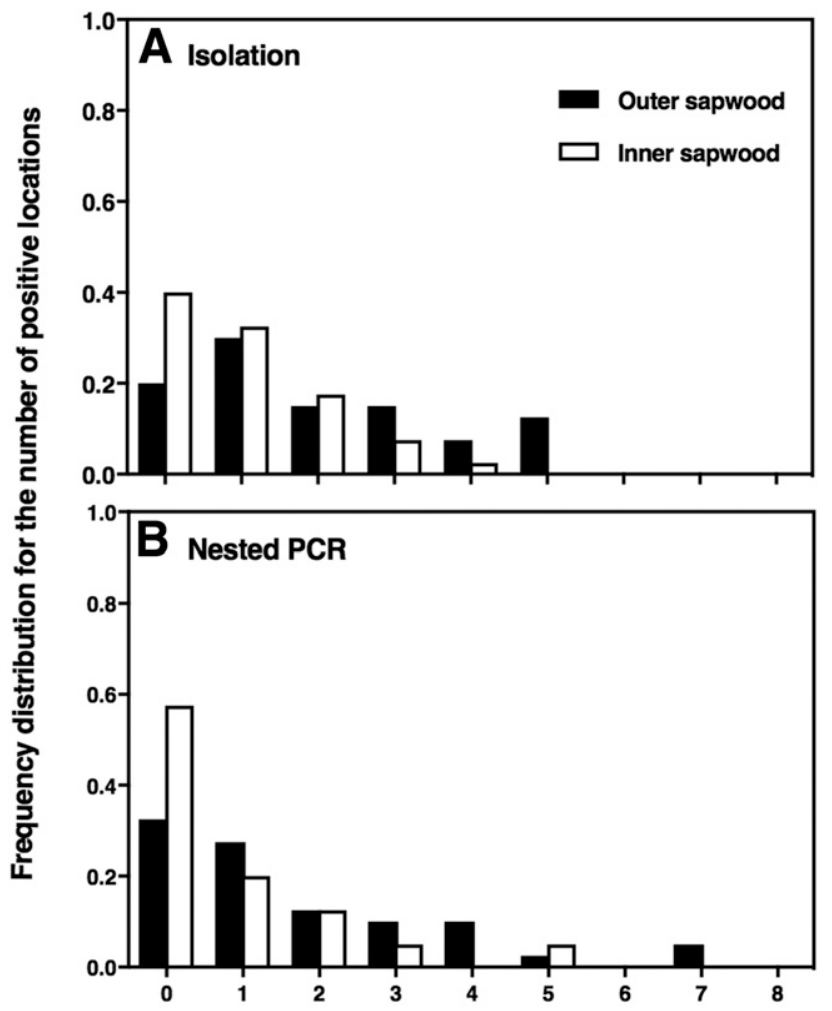

Number of locations per disk positive for $B$. fagacearum

Fig. 1. Proportion of subsamples yielding Bretziella fagacearum per disk from naturally infected Quercus rubra trees based on total number of subsamples assayed using (A) laboratory isolation techniques and (B) nested PCR prior to vacuum steam treatment. selected log depths and time required for each treatment regime. A preliminary report has been published (Yang et al. 2017).

\section{Materials and Methods}

Study trees. Between May and July of 2016, six Q. rubra (43.9 to $54.6 \mathrm{~cm}$ dbh) that had been infected naturally with $B$. fagacearum were selected in a 16.23 ha forest stand in East Farmington, WI. The stand was scheduled for harvesting as part of a timber sale during winter 2016. In addition, four healthy Q. rubra (41.91 to $55.4 \mathrm{~cm} \mathrm{dbh})$ were selected in the same stand for artificial inoculation with $B$. fagacearum. In late April 2016, one B. fagacearum isolate was obtained from sapwood of northern red oak in East Farmington, WI that had completely wilted during summer 2015, and a pure culture was grown on potato dextrose agar for 14 days under ambient laboratory temperature and lighting. Endoconidia were harvested by flooding the culture surface with sterile $\mathrm{dH}_{2} \mathrm{O}$ and filtering the resultant suspension through sterile cheese cloth. The spore suspension was quantified using a hemacytometer and diluted with sterile $\mathrm{H}_{2} \mathrm{O}$ to a concentration of approximately $1 \times 10^{6}$ conidia $/ \mathrm{ml}$. Trees were inoculated in early June 2016 using the following protocol. Soil was manually removed to expose three primary roots. One inoculation point was selected per root at approximately $0.3 \mathrm{~m}$ distal to the root collar. A $2.0 \mathrm{~cm}$ deep hole was drilled into the roots with a sterile $0.64 \mathrm{~cm}$ diameter drill bit. A $1.0 \mathrm{ml}$ spore suspension was applied through a $5.0 \mathrm{ml}$ pipette tip, which was held in place by using moldable epoxy putty. After uptake of the inoculum by the tree, the holes were sealed with the putty and roots were covered with the original soil. The AI trees were monitored through the summer of 2016 to document crown wilt progression. All study trees were felled in early September 2016. The main stems were cut into $2.4 \mathrm{~m}$ long logs and delivered to the treatment location at a biomass processing facility in Shakopee, MN.

Log description and experimental design. The ends of each log in the designated loads scheduled for treatment on a particular day were trimmed ( $22 \mathrm{~cm}$ length removed), and $8 \mathrm{~cm}$ thick disks were then taken from each end for pretreatment evaluation. The bark depth (outer bark plate to cambium), minimum bark depth (bottom of furrow to cambium), and depth from cambium to sapwood-heartwood boundary were measured at eight locations around each disk. Lastly, the length, end diameters, and weight of the now reduced-length logs (1.7 to $1.9 \mathrm{~m})$ from NI trees $(n=20 \operatorname{logs})$ and AI trees $(n=10 \operatorname{logs})$ were obtained.

The vacuum steam treatment schedules that were evaluated for ability to kill viable $B$. fagacearum in the $\log$ s were: 1) $56^{\circ} \mathrm{C}$ for $30 \mathrm{~min}$, and 2) $60^{\circ} \mathrm{C}$ for $60 \mathrm{~min}$. Each treatment schedule was replicated five times, with three logs treated in each test load (two NI and one AI logs per load). Logs of similar diameter were used in each load. Two AI logs were left untreated to determine whether ambient outdoor conditions reduced fungal viability over the time-course of the trial.

Log sampling and sample processing. The disks removed from the study logs prior to log measurement and vacuum steam treatment

Table 1. Number of locations yielding Bretziella fagacearum in culture or via nested PCR from the outer and inner sapwood of logs taken from naturally infected and artificially inoculated Quercus rubra trees prior to vacuum steam treatment

\begin{tabular}{|c|c|c|c|c|c|c|c|c|c|c|}
\hline \multirow{3}{*}{ Tree infection type } & \multirow{3}{*}{ Tree no. } & \multirow{3}{*}{ No. of logs } & \multicolumn{4}{|c|}{ Isolation $^{\mathbf{a}}$} & \multicolumn{4}{|c|}{ Nested PCR ${ }^{\mathbf{a}}$} \\
\hline & & & \multicolumn{2}{|c|}{ Outer } & \multicolumn{2}{|c|}{ Inner } & \multicolumn{2}{|c|}{ Outer } & \multicolumn{2}{|c|}{ Inner } \\
\hline & & & (No.) & $(\%)$ & (No.) & $(\%)$ & (No.) & $(\%)$ & (No.) & $(\%)$ \\
\hline \multirow[t]{6}{*}{ Natural } & 1 & 4 & 23 & 35.9 & 9 & 14.1 & 27 & 42.2 & 15 & 23.4 \\
\hline & 2 & 3 & 8 & 16.7 & 6 & 12.5 & 7 & 14.6 & 2 & 4.2 \\
\hline & 3 & 4 & 6 & 9.4 & 10 & 15.6 & 24 & 37.5 & 12 & 18.8 \\
\hline & 4 & 1 & 4 & 25.0 & 1 & 6.3 & 1 & 6.3 & 0 & 0.0 \\
\hline & 5 & 4 & 11 & 17.2 & 3 & 4.7 & 3 & 4.7 & 1 & 1.6 \\
\hline & 6 & 5 & 26 & 32.5 & 11 & 13.8 & 5 & 6.3 & 3 & 3.8 \\
\hline \multirow[t]{4}{*}{ Artificial } & 7 & 3 & 27 & 56.3 & 20 & 41.7 & 24 & 50.0 & 5 & 10.4 \\
\hline & 8 & 2 & 17 & 53.1 & 10 & 31.3 & 10 & 31.3 & 3 & 9.4 \\
\hline & 9 & 1 & 3 & 18.8 & 2 & 12.5 & 3 & 18.8 & 0 & 0.0 \\
\hline & 10 & 4 & 26 & 40.6 & 15 & 23.4 & 15 & 23.4 & 3 & 4.7 \\
\hline
\end{tabular}

a Two disks taken per log and eight locations per disk were used for isolation (four wood chips/location) and nested PCR (composited shavings from four to five drill penetrations) assays per disk at each sapwood depth $(n=16)$. 
were subsampled for pathogen assay. Bark was removed at locations around the circumference of each log disk using a sterile chisel. Eight locations were opened to the outer sapwood alternating with eight that were opened to the innermost sapwood. Care was taken so that the inner sapwood locations were one or two annual rings distal to the heartwood boundary. Each sapwood location was assayed for viable B. fagacearum. Four small $\left(6.4 \mathrm{~mm}^{2}\right)$ sapwood pieces were excised from vascular-stained sapwood using a sterile wood gouge and inserted in semiselective medium (Barnett 1953) in petri plates. Plates containing sapwood chips were incubated up to 21 days at room temperature (approximately $24^{\circ} \mathrm{C}$ ) under ambient lighting and were routinely monitored for presence of the fungus. Positive cultures were identified by the presence of brown to olive-green colonies, characteristic fruity odor, and the presence of endoconidia distinctive of $B$. fagacearum on the medium.

Approximately $1.0 \mathrm{ml}$ of drill shaving samples were collected from undisturbed sapwood of the same locations per Banik et al. (2013) to detect fungal DNA using a nested PCR protocol (Yang

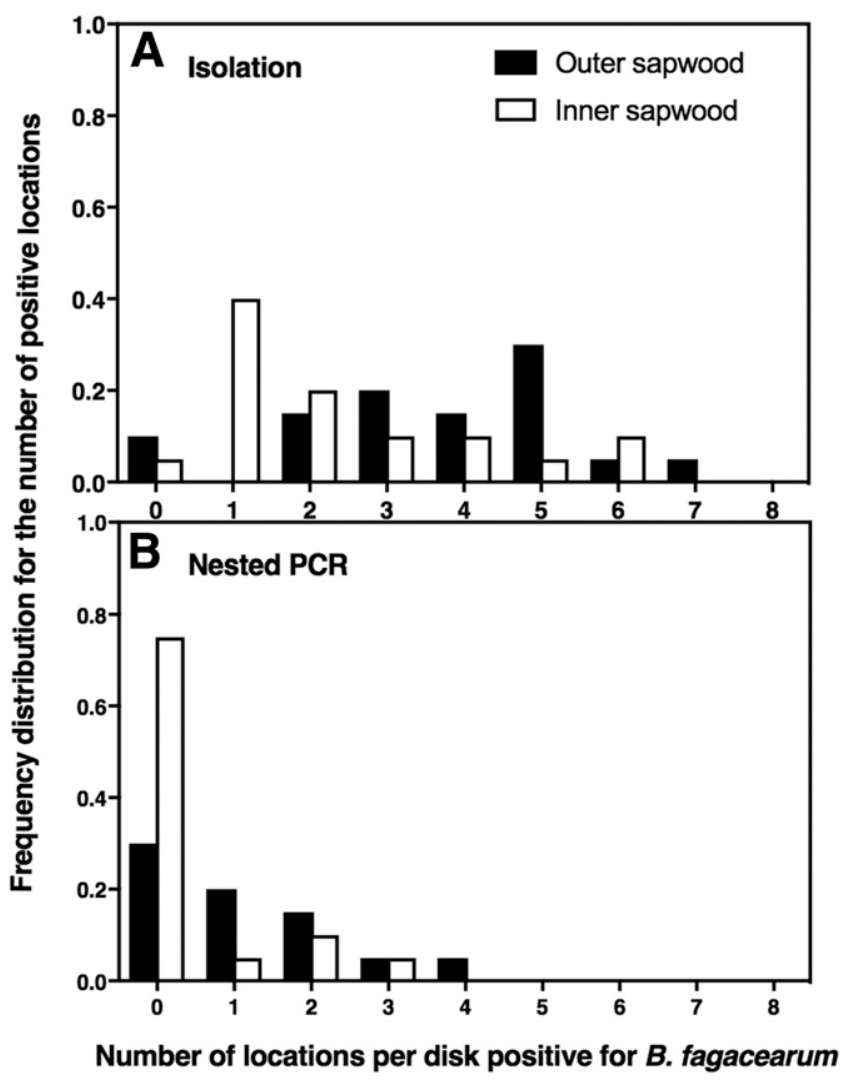

Fig. 2. Proportion of subsamples yielding Bretziella fagacearum per disk from artificially inoculated Quercus rubra trees based on total number of subsamples assayed using (A) laboratory isolation techniques and (B) nested PCR prior to vacuum steam treatment.

Table 2. Coefficients of the generalized linear mixed effects model fitted to the Bretziella fagacearum isolation data for locations of disks sampled prior to vacuum steam treatment. Disks were from logs obtained from wilted Quercus rubra trees, six naturally infected and four artificially inoculated with $B$. fagacearum. Artificially inoculated and inner sapwood are the reference levels.

\begin{tabular}{lccc}
\hline Variable & Coefficient estimate & SE & $\boldsymbol{P}$ value \\
\hline Intercept & -1.2587 & 0.1884 & $<0.0001$ \\
Natural infection & -0.8479 & 0.2581 & 0.001 \\
Outer sapwood & 0.4478 & 0.2191 & 0.041 \\
Natural infection $\times$ outer sapwood & 0.2155 & 0.3038 & 0.4781 \\
\hline
\end{tabular}

and Juzwik 2017). This method determined presence of both viable and nonviable $B$. fagacearum. Drill shavings in $2.0 \mathrm{ml}$ microcentrifuge tubes were covered with CTAB lysis buffer $(1.4 \mathrm{M} \mathrm{NaCl}$, $0.1 \mathrm{M}$ Tris-HCl, $20 \mathrm{mM}$ EDTA, 2\% CTAB, $\mathrm{pH}$ 7.0) and stored at $-20^{\circ} \mathrm{C}$ until further processed. DNA was extracted from the drill shavings following the technique of Banik et al. (2013). Amplification and sequencing of DNA was completed following Yang and Juzwik (2017).

Following treatment, logs were removed from the chamber and allowed to cool at ambient outdoor temperatures. When the logs were cool to the touch, disks were removed from the ends of each log as previously described. Isolation of $B$. fagacearum was attempted and collection of drill shavings was repeated in the same manner as described for the pretreatment samples. Sapwood samples were also removed from pretreatment and posttreatment sample disks for moisture content determination. Samples were oven-dried (approximately $103^{\circ} \mathrm{C}$ ) to constant weight. The average moisture content from each log (two disks per log) was calculated on a dry weight basis (per ASTM-D4442-07 standards).

Temperature and energy consumption monitoring. Holes were drilled to different depths along the length of each log, and Omega $\mathrm{K}$ type thermocouple wires (TT-K- $24 ; 260^{\circ} \mathrm{C} \max$ ) were inserted to the bottom of each hole and wire sealed with moldable epoxy putty (Chen et al. 2017a) (Supplementary Figure S1). Real-time thermal mapping data of temperature profiles within the logs during treatment was acquired from the thermocouple wire probes and recorded. Energy usage for each test was measured using a linepowered ELITEpro XC (Dent Instruments, Bend, OR) power meter that was installed at the testing location. Energy use was recorded as kilowatt hours ( $\mathrm{kWh}$ ), then converted to $\mathrm{kWh}$ per $\mathrm{kg}$ of wood treated $(\mathrm{kWh} / \mathrm{kg})$.

Vacuum steam treatment. Logs were end-sealed with liquid paraffin (Anchor Seal, U C Coatings, Buffalo, NY) prior to vacuum steam treatment. The treatment system consisted of an 80 $\mathrm{Kw}$ electric boiler (Reimers Electra Steam, Clear Brook, VA), a 5 hp dry claw vacuum pump (Busch LLC, Virginia Beach, VA), and a custom built vacuum chamber (Vacutherm Inc., Warren, VT) $(1.5 \times 1.5 \times 3.0 \mathrm{~m}$ capacity) that was mounted in the rear of a $6.5 \mathrm{~m}$ long enclosed trailer as described in White et al. (2017). All treatment replicates began with an initial vacuum of $100 \mathrm{mmHg}$. Once the initial vacuum was reached, saturated steam $\left(85^{\circ} \mathrm{C}\right)$ was added to the chamber. The chamber temperature was monitored and maintained through the entirety of the treatment until target temperature was reached for all probes placed at the $5.0 \mathrm{~cm}$ depth. Each treatment was stopped when the specified treatment time for the target temperature was achieved at the $5.0 \mathrm{~cm}$ depth. The steam was then shut off for the specified holding period; then the vacuum was released and the chamber door opened so that steam and condensate could be evacuated.

Data summarization and statistical analysis. Generalized linear effects models (Agresti 2002) were used to identify differences in detected colonization from the outer and inner sapwood in naturally infected and artificially inoculated trees using isolation and nested PCR. The mixed effects model has the form:

$$
\begin{gathered}
Y_{i j k l} \sim \operatorname{Binomial}\left(16, P_{i j k l}\right) \\
\operatorname{Logit}\left(Y_{i j k l}\right)=\mu+I_{i}+D_{j}+I D_{i j}+\alpha_{k}+\gamma_{l(k)}
\end{gathered}
$$

where $\mu$ is the overall mean, $I$ is the infection type (natural or artificial), $D$ is the sapwood depth (outer or inner), $\alpha$ is the error associated with tree number, and $\gamma$ is the error associated with $\log$ number. All calculations were carried out using $\mathrm{R}$ (version 1.0.143; R Foundation for Statistical Computing, Vienna). Odds ratios and estimated probabilities of detecting the fungus from the outer and inner sapwood of naturally infected and artificially inoculated trees were conducted using the lsmeans package in $\mathrm{R}$ (Lenth 2016). A fixed effect for log number was added to both models to determine if the position of a log within tree had an effect on detected colonization. 
Additional generalized linear models were developed to determine if differences in pathogen detection existed between trees of the same infection type. The models have the form:

$$
\operatorname{Logit}\left(Y_{k l}\right)=\mu+T_{k}+\alpha_{k}+\gamma_{l(k)}
$$

where $\mu$ is the overall mean, $T$ is tree number, $D$ is the sapwood depth, $\alpha$ is the error associated with tree number, and $\gamma$ is the error associated with log number. A Tukey pairwise comparison test was used to control for multiple comparisons between trees within either of the infection types.

\section{Results}

Log characteristics. Following the removal of pretreatment disks for measurement and assay, the logs ranged from 1.72 to $1.93 \mathrm{~m}$ in length (Supplementary Table S1). The small end diameter (inside bark) ranged from 23.5 to $49.5 \mathrm{~cm}$ and the log weights ranged from 86.1 to $408.5 \mathrm{~kg}$. The mean bark depth was $1.57 \mathrm{~cm}$ and the mean distance from the bark furrow to the cambium was $0.70 \mathrm{~cm}$. The average width of the sapwood of pretreatment disks was $0.93 \mathrm{~cm}$.

Pathogen presence in logs. B. fagacearum was isolated from at least one of four chips taken from each assayed location on disks from NI $Q$. rubra logs before VS treatment. The mean rates of isolation were $24.4 \%$ of the outer sapwood isolation locations $(n=160)$ and $12.5 \%$ of the inner sapwood locations $(n=160)$ (Fig. 1; Table 1). In logs from AI trees, the fungus was isolated from at least one of four chips from each assayed location in $45.6 \%$ of the outer sapwood locations $(n=80)$ and in $29.4 \%$ of the inner sapwood locations $(n=80)$ (Table 1). Frequencies of fungus isolation differed by tree infection type $(P=0.0010)$ and sapwood location $(P=0.0410)$ (Fig. 2; Table 2). The estimated probability of isolation was highest for samples taken from the outer sapwood of AI trees and lowest for samples obtained from inner sapwood of NI trees (Table 3). When all other variables were kept constant in each comparison, the odds of success (shown in parentheses) of isolating B. fagacearum from study logs were significant for: (a) AI versus NI trees (2.1 to 1 ; $P=0.0001)$, (b) inner versus outer sapwood locations (0.6 to $1 ; P=$ 0.0003 ), (c) inner sapwood locations of AI versus NI trees (2.3 to $1 ; P=0.0010)$, and (d) outer sapwood locations of AI versus NI trees (1.9 to $1 ; P=0.0035$ ). The position of the sampled log within a tree had no effect on the detected colonization in the isolation assay. No differences ( $P \geq 0.2762$; Tukey pairwise comparison) were found for pathogen presence among logs within NI trees or within AI trees.

$B$. fagacearum was detected in logs of NI $Q$. rubra using the nested PCR assay in one tube of composited wood shavings for each disk location in 21.0 and $11.0 \%$ of the samples from the outer $(n=$ $160)$ and inner sapwood $(n=160)$ locations, respectively (Table 1). The fungus was detected by nested PCR in $33.0 \%$ of the outer sapwood $(n=80)$ locations and from $7.0 \%$ of the inner sapwood locations $(n=80)$ in logs from AI trees. Frequencies of fungus detection differed only by sapwood location (Table 4). The highest estimated probabilities of pathogen detection by nested PCR were similar for outer sapwood locations of both tree infection types, and lowest probabilities were similar for inner sapwood of both infection types (Table 5). When all other variables were kept constant in each comparison, the odds of success (shown in parentheses) of detecting B. fagacearum from oak wilt-killed $Q$. rubra were significant only for inner versus outer sapwood locations $(0.3$ to $1 ; P<$ $0.0001)$. No differences in detection were found for (a) NI versus AI trees $(P=0.6514)$, (b) inner sapwood locations of NI versus AI trees $(P=0.6961)$, and (c) outer sapwood location of NI versus AI tree logs. The position of the sampled log within a tree had no effect on the colonization detected by nested PCR. For the nested PCR assays, no differences ( $P \geq 0.1079$; Tukey pairwise comparison) were found for pathogen presence among logs within NI trees or within AI ones.

The pathogen was not isolated or detected by nested PCR from any logs after VS treatment of either $60^{\circ} \mathrm{C}$ for $60 \mathrm{~min}$ or $56^{\circ} \mathrm{C}$ for $30 \mathrm{~min}$.
B. fagacearum was isolated from at least one of four chips in $43.8 \%$ of the outer sapwood locations $(n=32)$ and $31.3 \%$ of the inner sapwood locations ( $n=32$ ) of two untreated (=control) logs for disks taken on the same day that pretreatment samples were obtained for the first $\operatorname{logs}$ that were treated. In comparison, the fungus was isolated from one or more wood chips taken from $28.1 \%$ of outer sapwood locations $(n=32)$ and $18.8 \%$ of inner sapwood locations $(n=32)$ for disks taken from the same two control logs at the conclusion of the experiments. Thus, fungus isolation rates for the control logs stored outdoors decreased by $15.7-12.5 \%$ for outer and inner sapwood locations, respectively, over the 6 days during which the treatments were performed.

Temperatures achieved, time and energy required for vacuum steam treatment. The average time for the $5.0 \mathrm{~cm}$ target probes to reach $56^{\circ} \mathrm{C}$ and hold for $30 \mathrm{~min}$ was $6.9 \mathrm{~h}$ (Table 6), and the average time to reach $60^{\circ} \mathrm{C}$ and hold for $60 \mathrm{~min}$ was $8.6 \mathrm{~h}$. Examples of temperature profiles for each treatment schedule are shown in Figure 3. The average energy consumption to treat to $56^{\circ} \mathrm{C}$ for $30 \mathrm{~min}$ and $60^{\circ} \mathrm{C}$ for $60 \mathrm{~min}$ was $25.4 \mathrm{kWh}$ and $36.7 \mathrm{kWh}$, respectively (Table 6).

Sapwood moisture content. Moisture content of sapwood in pretreatment disks ranged from 72.9 to $98.3 \%$ with an average of $87.6 \%$, as calculated on a dry weight basis (data not shown). In disks sampled after treatment, sapwood moisture contents ranged from 75.3 to $102.4 \%$ with an average of $87.5 \%$. Moisture content of the sapwood from log disks decreased by $0.1 \%$ (ave.) following vacuum steam treatment.

\section{Discussion}

B. fagacearum-colonized logs used in this study were obtained from recently wilted, $41-$ to $61-\mathrm{cm}$-diameter $Q$. rubra that had become infected through natural means or from artificial inoculations with the pathogen by the authors. Pathogen-colonized logs in previous $\log$ treatment studies were taken from one or the other of these two infection types (Jones 1973; MacDonald et al. 1985; Schmidt 1983; Schmidt et al. 1997; Woodward and Schmidt 1995). This study offers a direct comparison of colonization levels and patterns in logs from both types. Furthermore, the presence of the pathogen was assayed using a standard isolation protocol as a measure of viable

Table 3. Estimated probabilities of Bretziella fagacearum detection by isolation based on logistic regression of the interactions of infection type (naturally infected or artificially inoculated) and sapwood location (outer sapwood or inner sapwood)

\begin{tabular}{lccc}
\hline \multirow{2}{*}{$\begin{array}{l}\text { Tree infection } \\
\text { type }\end{array}$} & $\begin{array}{c}\text { Sapwood } \\
\text { location }\end{array}$ & \multicolumn{2}{c}{ Probability } \\
\cline { 3 - 4 } & Estimated $\pm \mathbf{S E}^{\mathbf{a}}$ & $\mathbf{A c t u a l}_{\mathbf{2}} \mathbf{\mathbf { S E } ^ { \mathbf { b } }}$ \\
\hline Natural & Outer & $0.1910 \pm 0.0224$ & $0.2437 \pm 0.0240$ \\
Natural & Inner & $0.1085 \pm 0.0175$ & $0.1250 \pm 0.0184$ \\
Artificial & Outer & $0.3077 \pm 0.0353$ & $0.4563 \pm 0.0393$ \\
Artificial & Inner & $0.2212 \pm 0.0324$ & $0.2938 \pm 0.0360$ \\
\hline
\end{tabular}

${ }^{a}$ Estimated probability based on logit transformation from model estimates.

${ }^{b}$ Actual probability based on calculated proportions from samples used in this study.

Table 4. Coefficients of the generalized linear mixed effects model fitted to the Bretziella fagacearum nested PCR detection data for locations of disks sampled prior to vacuum steam treatment from logs obtained from wilted Quercus rubra trees, six naturally infected and four artificially inoculated with $B$. fagacearum. Artificially inoculated and inner sapwood are the reference levels.

\begin{tabular}{lccr}
\hline Variable & Coefficient estimate & SE & $\boldsymbol{P}$ value \\
\hline Intercept & -2.8492 & 0.4578 & $<0.0001$ \\
Natural infection & 0.2204 & 0.5644 & 0.6961 \\
Outer sapwood & 1.5814 & 0.3514 & $<0.0001$ \\
Natural infection $\times$ outer sapwood & 0.2155 & 0.3038 & 0.4781 \\
\hline
\end{tabular}


fungus level and by using a direct pathogen DNA detection technique (extraction from sapwood and amplification using nested PCR) as a measure of both viable and nonviable fungus presence. Previously published studies relied on the standard isolation method only. Pretreatment isolation rates from our study logs differed by tree infection type and by sampled sapwood depth. Rates were higher for logs from AI trees than those from NI trees and higher for outer versus inner sapwood locations within each tree infection type. In addition, more uniform colonization of the sapwood circumference was found for the AI trees based on number of sapwood locations on a disk that yielded the fungus in culture. Tubajika and Barak (2011) speculated that results of efficacy trials for chemical fumigation treatments may be dependent on the level of wood colonization by a target fungus. Our comparative results of pretreatment colonization of logs from NI and AI oaks suggest that the latter source of logs may be preferable for such tests.

In addition, Tubajika and Barak (2011) suggested that results of efficacy trials also may be a reflection of the assay technique used. Detection via isolation has typically been done by plating small wood samples on oak wilt identification agar developed by Barnett (1953) in previously published log treatment studies (MacDonald et al. 1985; Schmidt 1983; Schmidt et al. 1997; Woodward and Schmidt 1995). Both standard isolation and direct DNA detection methods were used in our study for the following reasons. The fungus is not evenly distributed in the sapwood around the circumference of the main stems of recently wilted red oaks, particularly for naturally infected trees. Rather, vertical strips of vascular discoloration interspersed with clear cambium may be found depending on time since complete tree wilt (J. Juzwik, personal observation). Thus, a true negative isolation or DNA detection may be (but not always) obtained when samples are taken from nonstained tissue. However, difficulty in isolating $B$. fagacearum from diseased sapwood during

Table 5. Predicted probabilities of Bretziella fagacearum detection by nested PCR based on logistic regression of the interactions of infection type (naturally infected or artificially inoculated) and sapwood depth (outer sapwood or inner sapwood)

\begin{tabular}{lccc}
\hline & & \multicolumn{2}{c}{ Probability } \\
\cline { 3 - 4 } $\begin{array}{l}\text { Tree infection } \\
\text { type }\end{array}$ & $\begin{array}{c}\text { Sapwood } \\
\text { location }\end{array}$ & $\begin{array}{c}\text { Estimated } \pm \\
\mathbf{S E}^{\mathbf{a}}\end{array}$ & Actual $\pm \mathbf{S E}^{\mathbf{b}}$ \\
\hline Natural & Outer & $0.1276 \pm 0.0348$ & $0.2125 \pm 0.0229$ \\
Natural & Inner & $0.0673 \pm 0.0212$ & $0.1063 \pm 0.0172$ \\
Artificial & Outer & $0.2196 \pm 0.0635$ & $0.3250 \pm 0.0370$ \\
Artificial & Inner & $0.0547 \pm 0.0236$ & $0.0688 \pm 0.0366$ \\
\hline
\end{tabular}

${ }^{a}$ Estimated probability based on logit transformation from model estimates.

${ }^{b}$ Actual probability based on calculated proportions from samples used in this study. fall and winter months has been reported anecdotally by plant disease diagnostic laboratories (Yang and Juzwik 2017) even though such trees are subsequently found to be pathogen-positive. The DNA detection method has proven useful in such cases. Two naturally occurring conditions in the field that can lead to difficulty in consistently isolating $B$. fagacearum from actively wilting or recently wilted oaks are drought and overlap of multiple insect pest and pathogen problems. Reduced sapwood moisture content of living oaks associated with seasonal drought has been anecdotally found to hinder ability to isolate the pathogen from sapwood of suspect oaks in Wisconsin (B. Hudelson, Plant Diagnostic Clinic, University of WisconsinMadison, personal communication). Defoliation by gypsy moth (Lymantria dispar) not only increases difficulty in detecting oak wilt symptomatic branches, but often favors extensive colonization by pathogenic Armillaria species of oak (Wargo and Harrington 1991). The latter may hamper colonization or detection of B. fagacearum in sapwood of the lower stems and root collar area of such trees. Two-lined chestnut borer (Agrilus bilineatus) or the red oak borer (Enaphalodes rufulus) followed by extensive root colonization by Armillaria species are other pest-pathogen systems that hinder oak wilt detection and collection of $B$. fagacearum-positive sapwood for isolation (Lawrence, Moltzan, and Moser 2002; Wargo and Harrington 1991). B. fagacearum is considered a poor saprophyte as it is relatively quickly replaced in the stems and branches by secondary microbial colonizers in the year following complete crown wilt. Thus, fungus isolation rates for logs taken from NI trees may vary depending on the time of complete wilt in relation to harvest of logs for an eradication treatment trial. B. fagacearum has been detected in $\geq 1$-year-old dead stems of wilted red oaks using the direct DNA detection method, while standard isolation failed to do so (Yang and Juzwik 2017). Similar rates of detection in outer and inner sapwood locations were found for the two techniques in our study for NI trees in situations where source trees had completely wilted in 2015 or early summer 2016 prior to September 2016 tree felling. However, actual detection by isolation was higher (but not statistically tested) than detection by PCR for outer and inner sapwood of AI trees. This finding was not anticipated by the authors. In a recently published study (Yang and Juzwik 2017), similar or higher rates of B. fagacearum detection were found for nested PCR compared with isolation for assays conducted on sapwood from actively wilting branches of bur, red, and white oaks. Thus, the nested PCR protocol appeared to work well for branch samples in comparison with isolation, but not for sapwood of logs cut from main stems of completely wilted AI red oaks in the study reported here. We then hypothesized the "poorer" performance of the PCR protocol compared with isolation could be influenced by time since branch or whole tree wilt and location source of assay samples (i.e., branch versus main stem). Furthermore, the subsamples for assaying via PCR and via isolation were collected differently. Specifically, thin (depth-wise) "slivers" of sapwood were

Table 6. Total vacuum steam treatment time for either $56^{\circ} \mathrm{C}$ for $30 \mathrm{~min}$ or $60^{\circ} \mathrm{C}$ for $60 \mathrm{~min}$ to $5.0 \mathrm{~cm}$ depth in sapwood of Quercus rubra logs. Initial $200 \mathrm{mmHg}$ pressure and saturated steam at $90^{\circ} \mathrm{C}$.

\begin{tabular}{lcccccc}
\hline Treatment regime $^{\mathbf{a}}$ & Test $^{\mathbf{b}}$ & $\begin{array}{c}\text { Average initial log } \\
\text { temp. }\left({ }^{\circ} \mathbf{C}\right)\end{array}$ & $\begin{array}{c}\text { Total cycle } \\
\text { time (min) }\end{array}$ & $\begin{array}{c}\text { Heating rate } \\
\left(\mathbf{m i n} /{ }^{\circ} \mathbf{C}\right)\end{array}$ & Energy use (kwh) & Energy use (kwh/kg) \\
\hline $56^{\circ} \mathrm{C} / 30 \mathrm{~min}$ & 1 & 23.0 & 547 & 16.6 & $\mathrm{n} / \mathrm{a}^{\mathbf{c}}$ & $\mathrm{n} / \mathrm{a}$ \\
& 4 & 20.5 & 326 & 9.2 & 26.54 & 0.053 \\
& 5 & 20.5 & 354 & 10.0 & 21.01 & 0.066 \\
& 8 & 14.0 & 437 & 10.4 & 29.33 & 0.042 \\
$60^{\circ} \mathrm{C} / 60$ min & 9 & 15.0 & 402 & 9.8 & 37.81 & 0.045 \\
& 2 & 23.5 & 617 & 16.9 & 34.25 & 0.048 \\
& 3 & 19.0 & 478 & 11.7 & 36.51 & 0.053 \\
& 6 & 17.5 & 498 & 11.7 & 38.11 & 0.049 \\
& 7 & 19.0 & 593 & 12.0 & 37.52 & 0.050 \\
\hline
\end{tabular}

\footnotetext{
${ }^{a}$ When temperature at target depth $\left(5 \mathrm{~cm}\right.$ into sapwood) reached $56^{\circ} \mathrm{C}$ for all $3 \operatorname{logs}$ per test, treatment was continued for $30 \mathrm{~min}($ at $200 \mathrm{mmHg})$ for $56^{\circ} \mathrm{C}$ for $30 \mathrm{~min}$ treatment. Similarly, when temperature reached $60^{\circ} \mathrm{C}$ for all three logs per test, treatment was continued for $60 \mathrm{~min}$ for $60^{\circ} \mathrm{C}$ for $60 \mathrm{~min}$ treatment.

${ }^{\text {b }}$ Two logs per test were obtained from $Q$. rubra naturally infected with Bretziella fagacearum and one log obtained from $Q$. rubra artificially inoculated with B. fagacearum.

${ }^{\mathrm{c}}$ Energy use data collector was not installed until after test 1 of the treatment.
} 
removed from the tangential surface of the exposed disk locations for isolation assay, while radial penetration (up to $1.5 \mathrm{~cm}$ deep) was done with a 0.64 diameter drill bit to collect shavings for the PCR assay. In comparison, findings for $B$. fagacearum-colonized logs in separate 2017 chemical fumigation trials with artificially inoculated red oaks (Q. ellipsoidalis) found higher pathogen detection rates for nested PCR than isolation (89 versus $84 \%$ for outer sapwood; 53 versus $38 \%$ for inner sapwood) for 20 to $28 \mathrm{~cm}$ diameter red oak logs prior to treatment (Yang et al. 2018). In this case, study trees were artificially inoculated with the pathogen in early June 2016, complete crown wilt occurred in the subsequent 2 months, and the trees were harvested in late February 2017. We hypothesize that these smaller diameter oaks and the longer time period between inoculation and felling allowed for more extensive sapwood colonization compared with the situation for the vacuum steam study trees. Chances for positive pathogen detection from shavings of a radially penetrating drill bit would be greater in more extensively colonized sapwood. Conversely, frequencies of $B$. fagacearum isolation from naturally infected trees is inversely related to length of time since complete crown wilt starting at approximately 12 months (depending on tree diameter) and beyond. This is due to the relatively quick colonization by secondary microorganisms, as previously discussed.

The vacuum steam treatment (for either schedule tested) to $5.0 \mathrm{~cm}$ sapwood depth was apparently sufficient to degrade DNA of $B$. fagacearum based on our failure to detect the fungus in posttreatment logs using nested PCR. Overall, results of our study further validate the

A
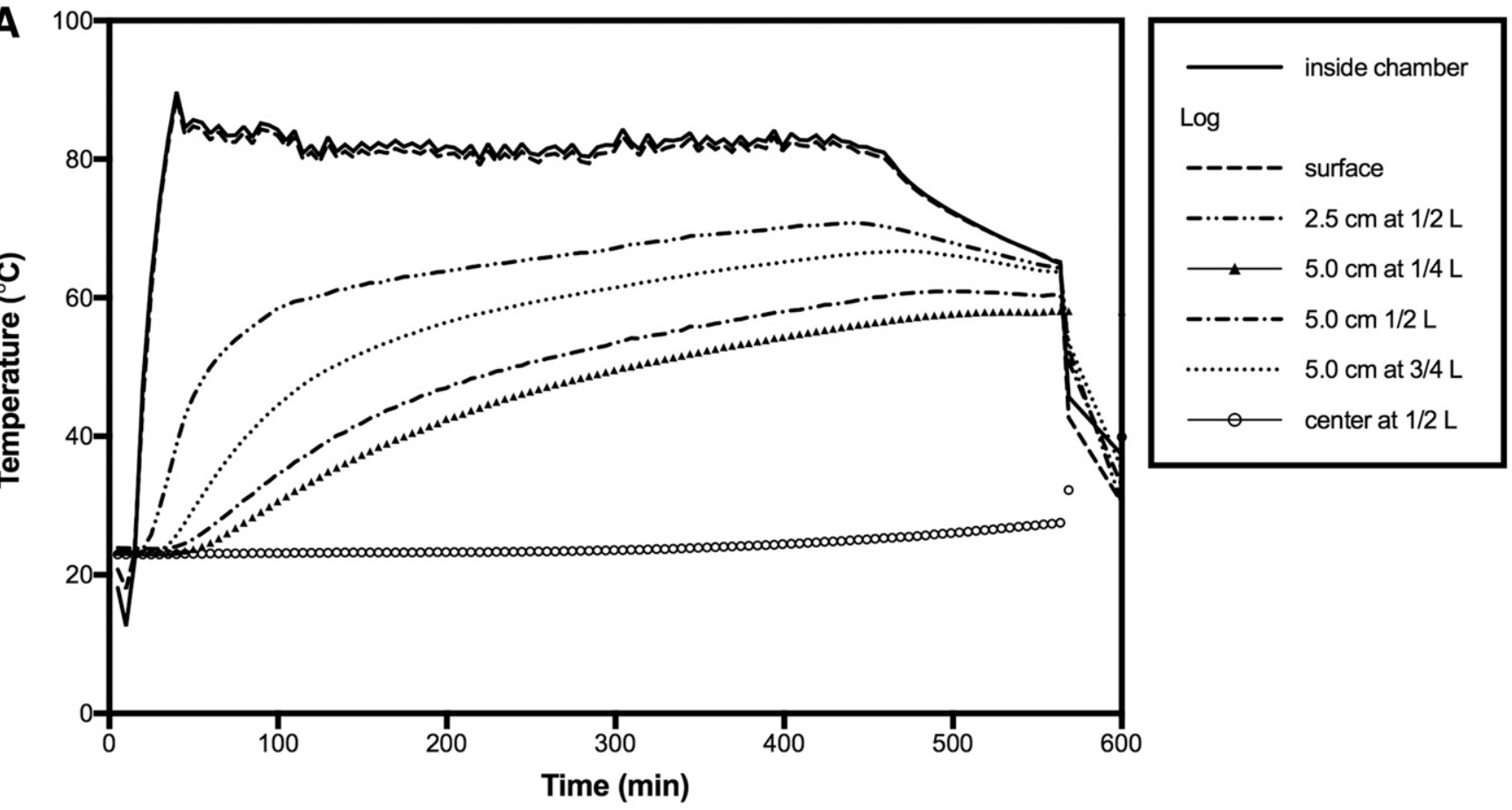

B

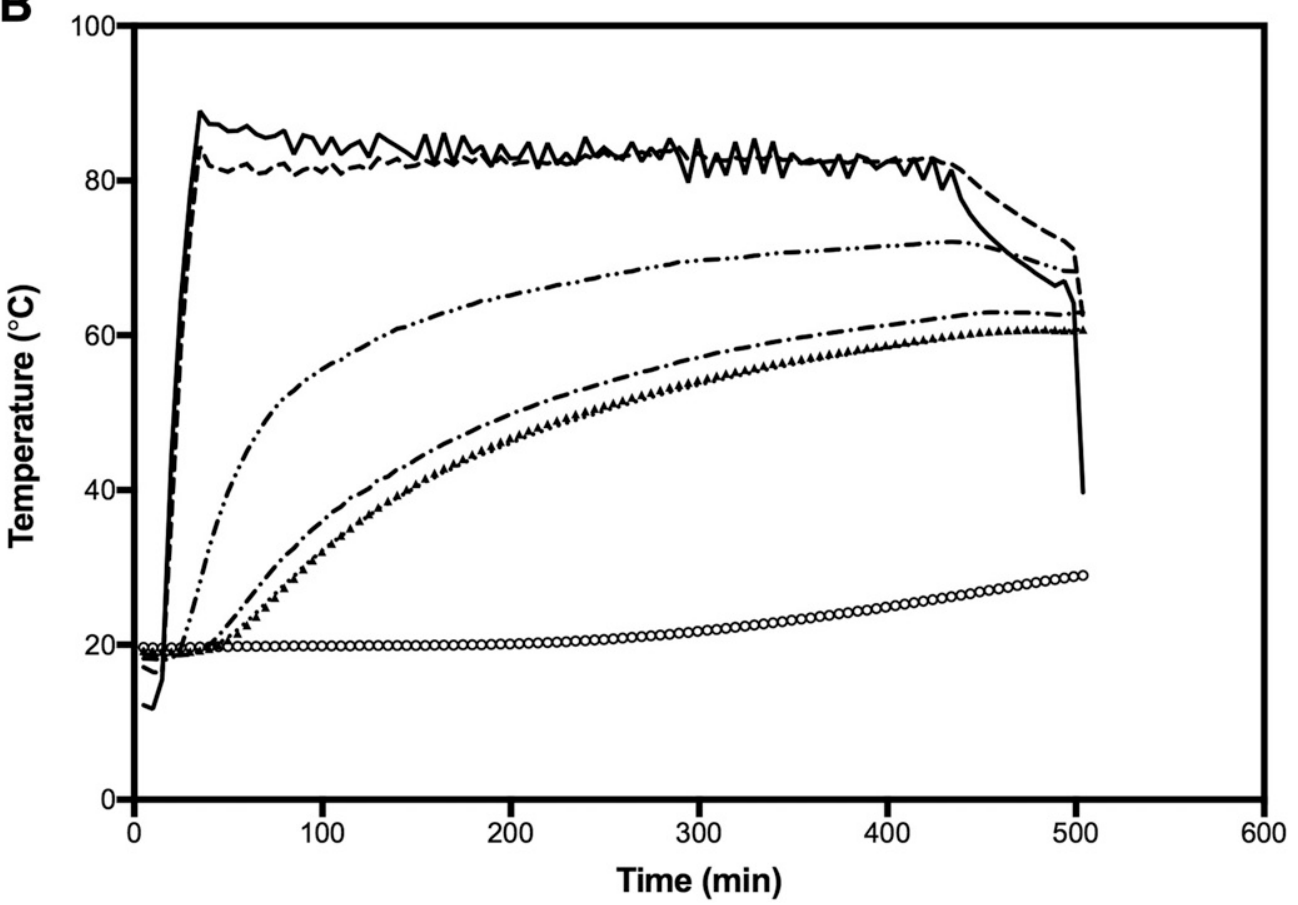

Fig. 3. Temperature profiles of $(\mathbf{A}) 56^{\circ} \mathrm{C}$ for 30 min treatment of Quercus rubra $\log 31$ and (B) $60^{\circ} \mathrm{C}$ for $60 \mathrm{~min}$ treatment of Quercus rubra log 21 at an initial vacuum of $100 \mathrm{mmHg}$. Temperature profiles based on the average temperature for every 5 min duration during vacuum steam treatment. 
use of the standard isolation method of culturing on oak wilt identification agar for evaluation of pathogen presence in log treatment trials.

Evaluation of phytosanitary log treatments benefit from reasonable and relatively uniform colonization levels of a virulent pathogen if one is testing the ability of a treatment to essentially eradicate the organism. Results of power analyses for our study based on the total number of sapwood locations sampled found a $99.8 \%$ confidence level that $B$. fagacearum could be detected from at least one location ( $n=640$ attempts) if $1 \%$ of the sapwood of NI logs was colonized. Confidence level was lower (95.9\%) for detection of the pathogen in at least one location if $1 \%$ of the sapwood from AI logs was colonized due to the fewer number of logs with a lower number of detection attempts $(n=320)$. In contrast, MacDonald et al. (1985) reported a probability of 0.993 of detecting $B$. fagacearum in at least 1 infected log of 18 tested if all test logs were $1 \%$ infected. This calculation is based on results for 40 samples (four chips taken from each of eight outer and eight inner sapwood locations). In retrospect for our study, scoring fungus presence based on results of individual wood pieces plated would have greatly increased the number of isolation attempts compared with scoring a sapwood location positive if one or more of the four chips taken at a location was positive. This approach will be incorporated in our future trials.

The VS treatment for all five log loads exposed to $56^{\circ} \mathrm{C}$ for $30 \mathrm{~min}$ at $5.0 \mathrm{~cm}$ sapwood depth were completed in 5 to $9 \mathrm{~h}$ (Table 6). Slightly longer treatment times ( 8 to $10 \mathrm{~h}$ ) were observed for the five log load replicates subjected to the $60^{\circ} \mathrm{C}$ for $60 \mathrm{~min}$ schedule. This treatment at the targeted depth resulted in eradication of viable $B$. fagacearum over a shorter time period than Jones (1973) reported for hot water treatment $\left(49^{\circ} \mathrm{C}\right.$ for $12 \mathrm{~h}$ to achieve eradication). Jones (1973) also used logs of smaller length and diameter than those used in this study. The results presented here also compare favorably with the MB schedule (T312) in the USDA Treatment Manual that specifies an extremely high MB dosage $\left(240 \mathrm{~g} / \mathrm{m}^{3}\right)$ for $72 \mathrm{~h}$ (USDA APHIS 2016). Heating to the $\log$ core (as in Chen et al. 2017a, b) is not necessary if the goal is to eradicate the pathogen from the tissues that it is known to colonize (e.g., phloem and sapwood for $B$. fagacearum), and would also unnecessarily burden prospective treatment facilities with added cost.

VS is an effective and efficient method of heating round and rectangular sections of wood (Simpson 2001). Furthermore, heat penetration of wood by steam under negative pressure is superior when compared with the questionable and limited penetration of logs by chemical fumigants such as sulfuryl fluoride and methyl bromide (Tubajika and Barak 2011). Other advantages for considering use of VS compared with chemical fumigation include the minimal level of harm to the environment, reduced human health concerns, and potentially faster treatment times. There are significant advantages to decreased treatment time that have direct and positive impact on business profitability and overall efficiency of port operations (e.g., reduced congestion). We found VS able to eliminate viable propagules of B. fagacearum from well-colonized oak logs, but the treatment would likely be effective for eradication of other pathogens and insect pests of logs (e.g., Geosmithia morbida and walnut twig beetle associated with thousand cankers disease) as well. Furthermore, the target depth of treatment and the treatment schedule could be developed specifically (tailored) for other pests and pathogens. The flexibility provided by VS treatment for logs would fit the current model in log trade, e.g., a bilaterally negotiated phytosanitary treatment schedule between trade partners that protects the importing country from unwanted phytosanitary risk.

Practical considerations for the continued development and potential use of VS for phytosanitary treatment include the fact that commercial VS chambers are already available in commerce for a variety of applications. These include devitalization of weed seeds in spices and bird seed upon import, conditioning of cotton bales for export, sterilization of mushroom substrates, and coloring of textiles among others. Vacuum steam treatment application for logs would likely be conducted at log holding yards or at shipping ports prior to movement. However, cost comparison studies for commercial scale-up (e.g., energy required for VS versus cost of chemical fumigation; chamber cost versus tarp treatment for fumigants) are needed if vacuum steam is to be considered a viable commercial option for the treatment of logs.

In summary, we report here the results of initial trials with VS for targeted treatment of oak logs to kill viable $B$. fagacearum propagules. We plan to conduct a second set of VS trials with logs from diseased red oaks in central or southern United States where sapwood depth is greater (and thus, target treatment depth is likely greater than that used in this study). To further position VS treatment of logs as a viable commercial entity, future tests will also consider a number of key operational aspects. Evaluation of numerous logs at scale in a fixed, commercial chamber is needed, as are considerations regarding log grouping by diameter. Optimal chamber design to accommodate the logistics of loading, treatment, and unloading should be thoroughly discussed with developmental partners in the treatment business community to enable a successful transition from methyl bromide to VS treatment for logs.

\section{Acknowledgments}

We thank J. Glaeser, J. Koch, and S. Pfister for helpful comments on the manuscript; P. Castillo, M. Moore, D. Iverson, and M. McDermott-Kubeczko for technical assistance; S. Nelson for locating site with study trees and providing logging industry contacts; and the Shakopee Mdewakanton Sioux Community for providing space, utilities, staff help, and forklift use for conduct of the study. The Statistical Consulting Center at the University of Minnesota and, in particular, H. Nilakanta helped with the analysis of this study.

\section{Literature Cited}

Agresti, A. 2002. Categorical Data Analysis. John Wiley \& Sons, Inc., Hoboken, NJ.

Banik, M. T., Lindner, D. L., Juzwik, J., and Glaeser, J. A. 2013. Use of DNA sequencing to detect pathogenic, saprotrophic, and stain fungi in sapwood of declining red pine (Pinus resinosa) in the Upper Midwest. Pages 101-110 in: Proc. 2012 Western International Forest Disease Work Conference. J. Browning, and P. Palacios, comps.

Barnett, H. L. 1953. Isolation and identification of the oak wilt fungus. W.V. Exp Stn. Bull. 359T.

Chen, Z., White, M., and Mack, R. 2017a. Evaluating vacuum and steam process on hardwood veneer logs for export. Eur. J. Wood Prod. 75:911-918.

Chen, Z., White, M., and Qiu, Z. 2017b. Investigation of vacuum and steam treatments to heat treat and sanitize firewood-grade ash $\operatorname{logs}$ and ash firewood. For. Prod. J. 67:258-265. https://doi.org/10.13073/FPJ-D-16-00045

Jones, T. W. 1973. Killing the oak wilt fungus in logs. For. Prod. J. 23:52-54.

Juzwik, J., Yang, A., Myers, S., Furtado, M., and Taylor, A. 2017. Survival of Ceratocystis fagacearum following red oak $\log$ fumigation with sulfuryl fluoride. (Abstr.) Phytopathology 107:S5.45. https://doi.org/10.1094/PHYTO107-12-S5.1

Lawrence, R., Moltzan, B., and Moser, K. 2002 (rev. 2010). Oak decline and the future of Missouri's forests. Missouri Conservationist Magazine, July 2002. (accessed 23 July 2018). https://mdc.mo.gov/conmag/2002/06-0/oak-declineand-future-Missouri-s-forests

Lenth, R. V. 2016. Least-squares means: The R package 1smeans. J. Stat. Softw. 69:1-33.

MacDonald, W. L., Schmidt, E. L., and Harner, E. J. 1985. Methyl bromide eradication of the oak wilt fungus from red and white oak logs. For. Prod. J. $35: 11-16$.

Partridge, A. D. 1961. Fumigants kill the oak wilt fungus in wood. For. Prod. J. 11: 12-14.

Pizano, M., and Banks, J. 2009. Montreal protocol substances that deplete the ozone layer and methyl bromide in the forest industry - use and alternatives. UNEP QPS Taskforce, Technology and Assessment Panel. Retrieved 5 April 2018 from http://www.uneptie.org/ozonaction/information/mmcfiles/7464-eMbr_Pizano.pdf

Scheffrahn, R. H., Su, N. Y., and Hsu, R. C. 1992. Diffusion of methyl bromide and sulfuryl fluoride through selected structural wood matrices during fumigation. Mater. Org. 27:147-155.

Schmidt, E., Juzwik, J., and Schneider, B. 1997. Sulfuryl fluoride fumigation of red oak logs eradicates the oak wilt fungus. Eur. J. Wood Prod. 55:315-318.

Schmidt, E. L. 1983. Minimum temperatures for methyl bromide eradication of Ceratocystis fagacearum in red oak log pieces. Plant Dis. 67:1338-1339.

Simpson, W. T. 2001. Heating times for round and rectangular cross sections of wood in steam. Gen. Tech. Rep. FPL-GTR-130. U.S. Department of Agriculture, Forest Service, Forest Products Laboratory, Madison, WI.

Tubajika, K. M., and Barak, A. V. 2006. Methyl iodide and sulfuryl fluoride as quarantine treatments for solid wood packing material. In: 2007 Annu. Int. Res. Conf. on Methyl Bromide Alternatives and Emissions Reductions, Jan. 2007, San Diego, CA. 
Tubajika, K. M., and Barak, A. V. 2011. Fungitoxicity of methyl iodide, sulfuryl fluoride, and methyl bromide to Ceratocystis fagacearum in red oak, maple, poplar, birch, and pine wood. Am. J. Plant Sci. 2:268-275

UNEP DTIE Energy and OzonAction Branch. 2002. The Montreal protocol control schedule and its evolution. Information paper. DTIE OzonAction Programme, OzonAction Information Clearinghouse. Accessed 5 April 2018 from http://www.unep.fr/ozonaction/information/mmcfiles/3326-e.pdf

USDA Animal and Plant Health Inspection Service (APHIS). 2016. Chemical Treatments: fumigants: methyl bromide. 2 TM. In: Treatment Manual. USDA APHIS PPQ. Accdssed 5 April 2018 from http://www.aphis.usda.gov/ import_export/plants/manuals/ports/downloads/treatment.pdf

Uzunovic, A., Mukherjee, A., Elder, P., and Myers, S. W. 2017. Rapid screening of sulfuryl fluoride as a potential phytosanitary treatment for a broad selection of fungi relevant to forestry. For. Prod. J. 67:4-12.

Wargo, P. M., and Harrington, T. C. 1991. Host stress and susceptibility. Chapter 7, pages 88-100 in: Armillaria Root Disease. C. G. Shaw III and G. A. Kile, eds. Agric. Handbook No. 691. U.S. Dep. Agric. For. Serv.
White, M. S., Chen, Z., and Mack, R. G. 2017. The effect of non-chemical phytosanitary treatment on the packaging integrity of unitized products to prevent the international spread of invasive plant and animal species. In: 2017 Proc. of ISTA TransPack Forum, Orlando, FL.

Woodward, R. P., and Schmidt, E. L. 1995. Fungitoxicity of sulfuryl fluoride to Ceratocystis fagacearum in vitro and in wilted red oak log sections. Plant Dis. 79:1237-1239.

Yang, A., and Juzwik, J. 2017. Use of nested and real-time PCR for the detection of Ceratocystis fagacearum in the sapwood of diseased oak species in Minnesota. Plant Dis. 101:480-486.

Yang, A., Juzwik, J., White, M., Chen, Z., Shugrue, S., and Mack, R. 2017 Vacuum steam treatment as a promising alternative to methyl bromide for killing Ceratocystis fagacearum in Quercus rubra logs for global export. (Abstr.) Phytopathology 107:S5.47. https://doi.org/10.1094/PHYTO-107-12-S5.1

Yang, A., Seabright, K., Juzwik, J., Myers, S.W., and Taylor, A. 2018. Survival of the oak wilt fungus in logs fumigated with sulfuryl fluoride and methyl bromide. For. Prod. J. doi.org/10.13073/FPJ-D-18-00033 